\title{
Single stage insertion of the Molteno tube for glaucoma and modifications to reduce postoperative hypotony
}

\author{
J E A HOARE NAIRNE, D SHERWOOD, J S H JACOB, AND W J C C RICH \\ From the West of England Eye Infirmary, Exeter
}

SUMMARY Severe glaucoma was controlled in all 13 cases following insertion of a Molteno drain in a single stage procedure. One eye required a repeat operation. A modified technique to minimise early postoperative hypotony and prevent flat anterior chambers is described

Standard filtering operations often have poor results in neovascular glaucoma, ${ }^{1}$ other severe cases of secondary glaucoma, and in cases complicated by unfavourable factors including aphakia, ${ }^{2}$ previous failed drainage surgery, ${ }^{34}$ or the youth of the patient. ${ }^{56}$ Cyclodialysis and cyclocryotherapy, techniques designed to reduce aqueous fluid production, have well recognised complications which include long term hypotony. ${ }^{78}$ Both are widely regarded as giving poor visual results.

The use of artificial implants to maintain aqueous fluid drainage dates from $1906 .{ }^{9}$ In 1969 Molteno first reported his work with an implant consisting of a silicone tube attached to an episcleral plate. ${ }^{10}$ The design was subsequently modified by lengthening the tube, allowing the plate to be sutured to the postequatorial sclera." Two interconnected episcleral plates, giving a total area of $270 \mathrm{~mm}^{2}$, have been shown to provide the optimum total bleb area. In many cases of neovascular glaucoma, however, the ciliary body is severely damaged, and a single plate is therefore preferable. ${ }^{12}$ Good results have been obtained with this system. ${ }^{13-18}$

\section{Materials and methods}

Patients were selected for Molteno tube surgery when medical therapy was no longer satisfactory and conventional surgery had already failed or was unlikely to have any reasonable chance of success. The eyes were divided into four groups relating to the cause of the raised intraocular pressure (Table 1). Previous intraocular surgery had been performed on

Correspondence to J E A Hoare Nairne, FRACS, Bristol Eye Hospital, Lower Maudlin Street, Bristol BS1 2LU. eight eyes. Five eyes with neovascular glaucoma had previously received panretinal photocoagulation (Tables 2-5).

The implant consists of a silicone tube with $0.6 \mathrm{~mm}$ outside and $0.3 \mathrm{~mm}$ inside diameter attached to one or two $13 \mathrm{~mm}$ diameter polymethylacrylate (PMMA) plates. Single plate implants were used for cases of neovascular glaucoma.

The plates were attached and tubes inserted in a one-stage procedure. Where two plates were used, the adjoining tube was passed underneath the superior rectus muscle. The plate(s) were secured in a postequatorial position with the tube lying radial to the limbus. A large partial thickness scleral flap, hinged at the limbus, was created to cover the entire length of the tube. In some cases cover was achieved with two separate flaps. The tube length was shortened to approximately 2 to $3 \mathrm{~mm}$ beyond the limbus,

Table 1 Patients receiving Molteno tube implants

\begin{tabular}{llll}
\hline $\begin{array}{l}\text { Treatment Diagnosis } \\
\text { group }\end{array}$ & $\begin{array}{l}\text { Number of } \\
\text { eyes treated procedures }\end{array}$ \\
\hline I & $\begin{array}{c}\text { Central retinal vein occlusion } \\
\text { with neovascular glaucoma }\end{array}$ & 4 & 5 \\
II & $\begin{array}{c}\text { Proliferative diabetic } \\
\text { retinopathy with neovascular } \\
\text { glaucoma }\end{array}$ & 3 & 3 \\
III & $\begin{array}{c}\text { Aphakic glaucoma } \\
\text { Miscellaneous: } \\
\text { Coats disease/neovascular } \\
\text { glaucoma }\end{array}$ & 1 & 3 \\
IV & $\begin{array}{l}\text { Heterochromic iridocyclits } \\
\text { Post endophthalmitis/chronic } \\
\text { angle closure }\end{array}$ & 1 & 1 \\
& Total & 13 & 1 \\
\hline
\end{tabular}


Table 2 Treatment group I (CRVO-NVG)

\begin{tabular}{|c|c|c|c|c|c|c|c|c|c|}
\hline & Age & $\operatorname{Sex}$ & $\begin{array}{l}\text { Panretinal } \\
\text { argon laser } \\
\text { photocoagulation }\end{array}$ & $\begin{array}{l}\text { Preoperative } \\
\text { visual acuity }\end{array}$ & $\begin{array}{l}\text { Postoperative } \\
\text { visual acuity }\end{array}$ & $\begin{array}{l}\text { Preoperative } \\
\text { intraocular } \\
\text { pressure }\end{array}$ & $\begin{array}{l}\text { Preoperative } \\
\text { ocular } \\
\text { medication }\end{array}$ & $\begin{array}{l}\text { Postoperative } \\
\text { intraocular } \\
\text { pressure }\end{array}$ & $\begin{array}{l}\text { Postoperative } \\
\text { ocular } \\
\text { medication }\end{array}$ \\
\hline 1 & 84 & $M$ & No & $\mathrm{CF}$ & HM & 32 & Timoptol Atropine & 70 & \\
\hline 2 & 84 & $\mathrm{M}$ & No & HM & $\mathrm{CF}$ & 70 & - r t & 16 & - \\
\hline 3 & 90 & $\mathbf{M}$ & No & HM & $\mathrm{CF}$ & 42 & Timoptol Atropine & 19 & Timoptol \\
\hline 4 & 77 & $\mathbf{M}$ & Yes & $6 / 60$ & PL & 40 & - & 6 & - \\
\hline 5 & 74 & $M$ & No & $\mathrm{CF}$ & $\mathrm{CF}$ & 26 & $\begin{array}{l}\text { Acetazolamide } \\
\text { Timoptol }\end{array}$ & 24 & - \\
\hline
\end{tabular}

$\mathrm{CRVO}=$ central retinal vein occlusion. $\mathrm{NVG}=$ neovascular glaucoma. $\mathrm{CF}=$ counting fingers at $0.5 \mathrm{~m} . \mathrm{HM}=$ hand movements. $\mathrm{PL}=$ perception of light.

Table 3 Treatment group II (PDR/NVG)

\begin{tabular}{|c|c|c|c|c|c|c|c|c|c|c|}
\hline & Age & Sex & $\begin{array}{l}\text { Panretinal } \\
\text { argon laser } \\
\text { photo- } \\
\text { coagulation }\end{array}$ & Prior surgery & $\begin{array}{l}\text { Preoperative } \\
\text { visual acuity }\end{array}$ & $\begin{array}{l}\text { Postoperative } \\
\text { visual acuity }\end{array}$ & $\begin{array}{l}\text { Preoperative } \\
\text { intraocular } \\
\text { pressure }\end{array}$ & $\begin{array}{l}\text { Preoperative } \\
\text { ocular } \\
\text { medication }\end{array}$ & $\begin{array}{l}\text { Postoperative } \\
\text { intraocular } \\
\text { pressure }\end{array}$ & $\begin{array}{l}\text { Postoperative } \\
\text { ocular } \\
\text { medication }\end{array}$ \\
\hline 1 & 66 & $\mathrm{~F}$ & Yes & $\begin{array}{c}\text { Extracapsular } \\
\text { cataract } \\
\text { extraction }\end{array}$ & HM & $\mathrm{PL}$ & 42 & Acetazolamide & 6 & - \\
\hline 2 & 63 & $\mathbf{M}$ & Yes & $\begin{array}{l}\text { Vitrectomy } \\
\text { and } \\
\text { lensectomy }\end{array}$ & $6 / 60$ & $6 / 60$ & 28 & $\begin{array}{l}\text { Timoptol } \\
\text { Acetazolamide }\end{array}$ & 18 & - \\
\hline 3 & 69 & $\mathrm{~F}$ & Yes & $\begin{array}{l}\text { Intracapsular } \\
\text { cataract } \\
\text { extraction, } \\
\text { vitrectomy }\end{array}$ & $\mathrm{CF}$ & $\mathrm{PL}$ & 33 & $\begin{array}{l}\text { Timoptol } \\
\text { Acetazolamide }\end{array}$ & 16 & - \\
\hline
\end{tabular}

PDR = proliferative diabetic retinopathy. $\mathrm{NVG}=$ neovascular glaucoma.

Table 4 Treatment group III (aphakic glaucoma)

\begin{tabular}{|c|c|c|c|c|c|c|c|c|c|}
\hline & Age & Sex & Prior procedure & $\begin{array}{l}\text { Preoperative } \\
\text { visual acuity }\end{array}$ & $\begin{array}{l}\text { Postoperative } \\
\text { visual acuity }\end{array}$ & $\begin{array}{l}\text { Preoperative } \\
\text { intraocular } \\
\text { pressure }\end{array}$ & $\begin{array}{l}\text { Preoperative } \\
\text { ocular medication }\end{array}$ & $\begin{array}{l}\text { Postoperative } \\
\text { intraocular } \\
\text { pressure }\end{array}$ & $\begin{array}{l}\text { Postoperative } \\
\text { ocular } \\
\text { medication }\end{array}$ \\
\hline 1 & 81 & $\mathrm{~F}$ & ICCE, ALT & $6 / 5$ & $6 / 9$ & 24 & $\begin{array}{l}\text { Acetazolamide } \\
\text { Timoptol }\end{array}$ & 19 & Timoptol \\
\hline 2 & 65 & $\mathrm{M}$ & $\begin{array}{l}\text { ICCE and IOL, } \\
\text { ALT }\end{array}$ & $6 / 5$ & $6 / 5$ & 28 & $\begin{array}{l}\text { Timoptol } \\
\text { Pilocarpine }\end{array}$ & 21 & $\begin{array}{l}\text { Timoptol } \\
\text { Pilocarpine }\end{array}$ \\
\hline 3 & 69 & $\mathbf{F}$ & $\mathrm{ICCE}$ & $6 / 36$ & $\mathrm{CF}$ & 24 & $\begin{array}{l}\text { Acetazolamide } \\
\text { Timoptol } \\
\text { Pilocarpine }\end{array}$ & 19 & Timoptol \\
\hline
\end{tabular}

ICCE $=$ intracapsular cataract extraction. $\mathrm{IOL}=$ intraocular lens. $\mathrm{ALT}=$ argon laser trabeculoplasty.

Table 5 Treatment group IV (miscellaneous)

\begin{tabular}{|c|c|c|c|c|c|c|c|c|c|c|}
\hline & Age & Sex & Diagnosis & $\begin{array}{l}\text { Previous } \\
\text { surgery }\end{array}$ & $\begin{array}{l}\text { Preoperative } \\
\text { visual acuity }\end{array}$ & $\begin{array}{l}\text { Postoperative } \\
\text { visual acuity }\end{array}$ & $\begin{array}{l}\text { Preoperative } \\
\text { intraocular } \\
\text { pressure }\end{array}$ & $\begin{array}{l}\text { Preoperative } \\
\text { ocular medication }\end{array}$ & $\begin{array}{l}\text { Postoperative } \\
\text { intraocular } \\
\text { pressure }\end{array}$ & $\begin{array}{l}\text { Postoperative } \\
\text { ocular } \\
\text { medication }\end{array}$ \\
\hline 1 & 30 & $\mathbf{M}$ & $\begin{array}{c}\text { Coats disease } \\
\text { neovascular } \\
\text { glaucoma }\end{array}$ & - & PL & PL & 55 & - & 6 & - \\
\hline 2 & 52 & $F$ & $\begin{array}{l}\text { Heterochromic } \\
\text { iridocyclitis }\end{array}$ & ICCE & $6 / 6$ & $6 / 9$ & 38 & $\begin{array}{l}\text { Timoptol } \\
\text { Acetazolamide }\end{array}$ & 12 & - \\
\hline 3 & 71 & $\mathrm{~F}$ & $\begin{array}{l}\text { Postoperative } \\
\text { endophthal- } \\
\text { mitis }\end{array}$ & $\begin{array}{l}\text { ECCE and } \\
\text { IOL, PK, } \\
\text { trabecul- } \\
\text { ectomy }\end{array}$ & HM & HM & 45 & $\begin{array}{l}\text { Timoptol } \\
\text { Acetazolamide }\end{array}$ & 16 & - \\
\hline
\end{tabular}

$E C C E=$ extracapsular cataract extraction. $\mathrm{PK}=$ penetrating keratoplasty. 
thus allowing for postoperative tube retraction. The tube was inserted into the anterior chamber through a narrow incision and the scleral flap(s) closed securely with interrupted $8 / 0$ virgin silk sutures. The same suture was used for the conjunctiva.

In six cases a $3 / 0$ polypropylene suture was passed through the tube (Fig. 1). The presence of the suture, which acts as a splint, greatly facilitates the insertion of the tube into the anterior chamber. The distal end of the suture was passed over the plate, under the superior and horizontal rectus muscles, and secured to sclera (Fig. 2). The proximal end of the suture remained in the tube. Removal six weeks later, under local anaesthesia, was through a small conjunctival incision over the distal end of the suture, well away from the drainage site.

In one case the Vicryl tie procedure was employed. ${ }^{19}$ A $6 / 0$ Vicryl suture was tied round the tube under the scleral flap so as to occlude the lumen (Table 6).

All cases received preoperative chloramphenicol drops. The postoperative regimen was atropine drops $1 \%$ twice daily, adrenaline drops $1 \%$ three

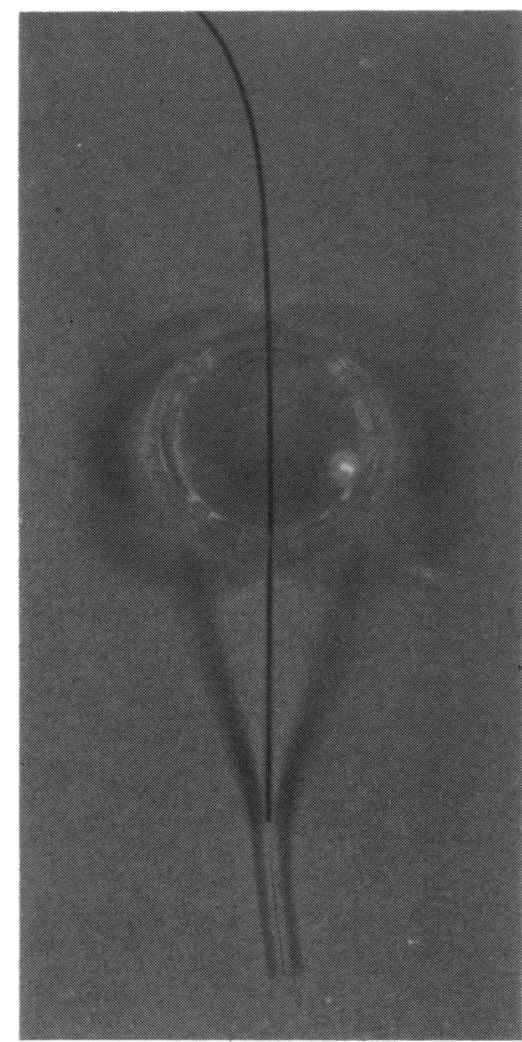

Fig. 1 Single plate Molteno tube with 3/0 polypropylene suture.

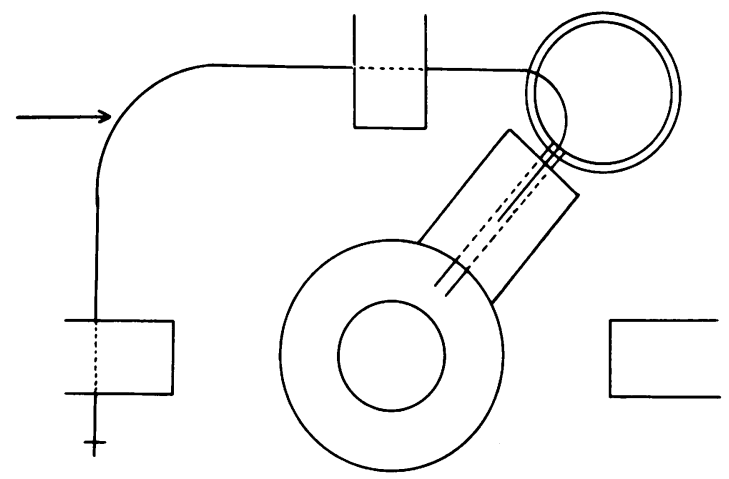

Fig. 2 3/0 Polypropylene suture (arrow) is inserted half way down the Molteno tube, passed under the superior and horizontal rectus muscles, and secured to sclera.

times a day, and betamethasone drops four times a day for six weeks. Adrenaline drops were not used for more than one week on intracapsular aphakic eyes. Additional systemic medication was given to four patients: group III patient 2 and group IV patients 1 and 3 were given oral prednisolone $10 \mathrm{mg}$ three times a day, colchicine $0.25 \mathrm{mg}$ three times a day, and indomethacin $25 \mathrm{mg}$ three times a day for five weeks. In group I, patient 5, unable to tolerate the full regimen, was given oral prednisolone $10 \mathrm{mg}$ three times a day for three weeks.

\section{Results}

Tables 2-5 show that all cases, with the exception of case 1 in group I, achieved an intraocular pressure less than $25 \mathrm{mmHg}$. The mean fall in pressure was 23 $\mathrm{mmHg}$. Four eyes, three of which had aphakic glaucoma, required additional antiglaucoma drops. The mean follow-up was 14 months, with a range of 6 to 27 months. In group I patient 5 died three months after the operation. All eyes retained vision, seven eyes showed a small deterioration, and two eyes a

Table 6 Operative procedures

\begin{tabular}{ll}
\hline Procedure & Number \\
\hline Single plate Molteno tube & 7 \\
Single plate and 3/10 Prolene & 3 \\
Double plate and 3/0 Prolene & 3 \\
Double plate and Vicryl tie procedure & 1 \\
\hline
\end{tabular}


Table 7 Postoperative complications

\begin{tabular}{lllll}
\hline Procedure & No. & Hyphaema & $\begin{array}{l}\text { Vitreous } \\
\text { haemorrhage }\end{array}$ & $\begin{array}{l}\text { Vitreous face } \\
\text { opacation }\end{array}$ \\
\hline Open tubes & 7 & 7 & - & - \\
Tubes with 3/0 Prolene & 6 & 5 & 1 & 2 \\
Tube with Vicryl tie & 1 & 1 & - & - \\
\hline
\end{tabular}

Table 8 Postoperative complications

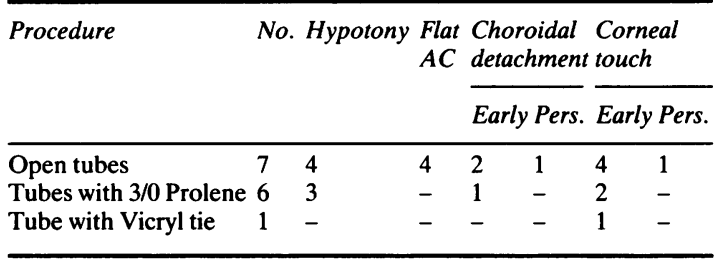

$\mathrm{AC}=$ anterior chamber. Pers. $=$ persistent.

small improvement in visual acuity. There were no cases of infection.

Case 1 in group I developed profound hypotony, with choroidal detachment and a flat anterior chamber, after insertion of a single plate tube without an intraluminal $3 / 0$ polypropylene suture. On the fourteenth day iris occluded the tube, resulting in a sharp rise in intraocular pressure. Attempts to clear the tube failed. The original implant was removed, and a single plate tube with a $3 / 0$ polypropylene suture was inserted at a fresh site (recorded as group I case 2). Transient obstruction by iris was observed in one other case without a $3 / 0$ polypropylene suture.

In the first case where the polypropylene was used postoperative retraction of the Molteno tube resulted in protrusion of the suture into the anterior chamber (case 2, group III). This required adjustment under local anaesthesia on day 4 . In all subsequent cases the polypropylene sutures were withdrawn half way up the tube, before they were secured to the sclera, at the time of the initial operation. Other complications are summarised in Tables 7 and 8 . Hypotony, defined here as an intraocular pressure less than $2 \mathrm{mmHg}$, was found in the early postoperative phase in seven eyes. Five of these eyes had neovascular glaucoma. Associated flat anterior chambers were found in four eyes, all with open tubes. No flat anterior chambers were found in eyes where the suture had been placed in the tube. One case of choroidal detachment and one case of corneal touch persisted beyond 10 days, both in eyes with open tubes.

During the first eight postoperative weeks there were six cases of raised intraocular pressure. The maximum reading was $35 \mathrm{mmHg}$, and all returned to normal by the end of this period. In two cases the polypropylene suture was removed early, at three weeks, in each case producing a significant drop in pressure (group I, patient 4, and group IV, patient 2).

Postoperative hyphaema was present in 12 eyes, and all cleared in the first fortnight. There were no cases of obstruction of the tube with blood clot.

The two cases of vitreous face opacification occurred in the aphakic glaucoma group (group III, patients 1 and 2). In both cases treatment with the YAG laser resulted in vitreous entering the tube causing a rise in intraocular pressure. In patient 2 partial clearance was obtained with further .YAG laser applications to the vitreous within and adjacent to the tube. Control of the intraocular pressure was regained with the use of additional topical treatment.

\section{Discussion}

In the absence of surgical damage to the ciliary body postoperative hypotony is often a consequence of continued excessive escape of aqueous fluid. In a series of 30 single-plate Molteno tubes, inserted in a one-stage procedure, seven flat anterior chambers were reported in the first postoperative week and one of these resulted in failure. ${ }^{16}$ In this series four out of 13 eyes had flat anterior chambers in the first week, and all achieved a satisfactory final result.

Obstruction of the tube by iris or vitreous occurring after single-stage insertion has been described and associated with excessive aqueous drainage..$^{1314}$ In this series two cases of obstruction by iris coincided with hypotony, and in one case this caused a serious rise in intraocular pressure, necessitating a repeat operation. Interestingly our two cases of vitreous entry into the tube occurred after YAG laser treatment, a previously unrecognised complication of this procedure.

Molteno advocates insertion of the tube in a twostage procedure, permitting a thin layer of fibrous tissue to surround the plate, thereby creating some resistance to the passage of aqueous fluid. Good results were obtained, and the technique also reduced the incidence of hypotony and secondary obstruction of the tube with iris or vitreous. ${ }^{13}$ There are, however, two main disadvantages with a twostage procedure: the condition of the eye may not permit such a delay and two major operations are required.

One alternative is temporarily to occlude the lumen of the tube by tying an absorbable suture round the outside. With a single loop of $5 / 0$ Vicryl suture the tube has been shown to open up after an average of four weeks, with a few cases possibly taking up to eight weeks. Good results have been reported with this method. ${ }^{19}$ Molteno et al. have reported that, with a 22 gauge needle for entry into the anterior chamber, leakage of aqueous fluid outside the occluded tube ceased a few minutes after 
insertion. Continued treatment with glaucoma medication was required until the tube reopened. This method has successfully eliminated the necessity of a second-stage operation, but the problem of potential delay in adequate control of intraocular pressure still remains.

The technique we have used in an attempt to overcome these problems is temporarily to partially occlude the lumen of the Molteno tube by inserting $3 / 0$ polypropylene down its length. The presence of the suture, while permitting the flow of some aqueous fluid, greatly reduces the overall drainage and, if required, could be used to clear any obstruction of the tube by iris, vitreous, or blood. The intention is to provide immediate control of intraocular pressure, without profound hypotony, with simultaneous limited deposition of fibrous tissue round the episcleral plate. The polypropylene, acting as a splint, also facilitates insertion of the tube into the anterior chamber at the time of operation.

The numbers in the study are too few to demonstrate conclusively a modifying effect of the intraluminal $3 / 0$ polypropylene suture. These first results, however, suggest that hypotony may be mitigated but not prevented. Aqueous drainage outside the tube is unaffected by the suture, and despite a narrow anterior chamber incision we believe in some cases contributes to the lowering of the intraocular pressure in the early postoperative phase. Hypotony is therefore not eliminated. In contrast to the open tubes, however, no flat anterior chambers were observed with the $3 / 0$ polypropylene suture. In the two cases of early suture withdrawal a fall in intraocular pressure was observed, demonstrating an increase in aqueous flow. It is probable that a more complete fibrous lining to the bleb accounts for the absence of a pressure drop on withdrawal at six weeks. ${ }^{13}$

The histology of functioning and failed blebs is well recognised. ${ }^{1120-25}$ Evidence exists for a role of aqueous fluid in fibroblast growth in tissue culture and in bleb fibrosis. ${ }^{20-30}$ In a monkey model aqueous aspirated from eyes that had previously undergone filtration surgery supported growth of tissue cultures of subconjunctival fibroblasts. This ability to support growth diminished with increasing postoperative interval. $92 \%$ of cultures were positive with aqueous samples removed at one week, $75 \%$ at four weeks, and $33 \%$ at eight weeks. ${ }^{27}$ This duration is similar to the period of postoperative bleb inflammation and associated increased intraocular pressure observed by Molteno et al. ${ }^{28}$

To minimise excessive bleb fibrosis Molteno advocates the use of a long tube in a two-stage or Vicryl tie procedure together with administration of oral prednisone, fluphenamic acid, and colchicine. ${ }^{11} 13_{192831}$ Brown and Cairns did not find improved results in patients given this systemic medication. ${ }^{16}$ In our series four patients received oral enteric coated prednisolone, indomethacin, and colchicine. The full regimen was tolerated in three of these patients. The numbers at this stage are too small to demonstrate the effect on final results.

Other studies to assess pharmacological modification of drainage surgery have been undertaken. In a randomised prospective trial, which excluded patients with aphakia or previous drainage surgery, Starita et al. showed the success rate of trabeculectomy to be improved by topical steroids, with no additional benefit from systemic steroids. ${ }^{32}$ Topical indomethacin has been shown to have an adverse effect.$^{33}$ Fourteen out of 15 eyes with increased risk of filtration failure had successful trabeculectomies following preoperative subconjunctival triamcinolone.$^{34}$ The place of 5-fluorouracil, while the drug appears to be potentially useful, remains to be established. ${ }^{35-38}$ The results of further studies on animals and humans are awaited.

Encouraging results, without the use of systemic medication, have been obtained with a tube attached to an encircling band. ${ }^{39}{ }^{40}$ Schocket $e t$ al. point out that success depends on the formation of scar tissue. Fourteen out of 30 eyes in their series had flat anterior chambers and, significantly, all had neovascular glaucoma..$^{39}$ Drainage into a large surface area with a one-piece system incorporating a valve has been reported to have a much lower incidence of flat anterior chamber. ${ }^{41}$

The optimum early postoperative aqueous fluid flow rate and the optimum ratio of drainage area to fibrous well thickness, for tube systems used in glaucoma, remain to be determined.

We believe the results of single-stage insertion of the Molteno tube and the temporary presence of an intraluminal suture are encouraging.

While the use of the systemic antifibrosis regimen is inconclusive in this study, we accept that there is a need for vigorous suppression of inflammation and fibrosis in some cases of Molteno tube surgery.

\section{References}

1 Allen RC, Bellows R, Hutchinson T, et al. Filtration surgery in the treatment of neovascular glaucoma. Ophthalmology 1982; 89: 1181-7.

2 Bellows AR, Johnstone MA. Surgical management of chronic glaucoma in aphakia. Ophthalmology 1983; 90: 807-13.

3 Schwartz AL, Anderson DR. Trabecular surgery. Arch Ophthalmol 1974; 92: 134-8.

4 Cohen JS, Shaffer RB, Hetherington J, et al. Revision of filtration surgery. Arch Ophthalmol 1977; 95: 1612-5.

5 Gressel MG, Heuer DK, Parrish RK. Trabeculectomy in young patients. Ophthalmology 1984; 91: 1242-6.

6 Beauchamp GR, Parks MM. Filtering surgery in children: barriers to success. Ophthalmology 1979; 86: 171. 
7 Haas JS. Glaucoma surgery. In: Iliff NT, ed. Complications in ophthalmic surgery. Edinburgh: Churchill Livingstone, 1983: 189-91.

8 Krupin T, Mitchell KB, Becker B. Cyclocryotherapy in neovascular glaucoma. Am J Ophthalmol 1980; 89: 338-43.

9 Rollet M. Traitement de l'hypopyon par le drainage capillaire de la chambre antèrieure. Rev Gen Ophtalmol (Paris). 1906; 25: 481-9.

10 Molteno ACB. New implant for drainage in glaucoma: clinical trial. Br J Ophthalmol 1969; 53: 606-15.

11 Molteno ACB, Straughan JL, Ancker E. Long tube implants for draining glaucoma. $S$ Afr Med J 1976; 50: 1062-6.

12 Molteno ACB. The optimal design of draining implants for glaucoma. Trans Ophthalmol Soc NZ 1981; 33: 39-41.

13 Molteno ACB, Van Biljon G, Ancker E. Two stage insertion of glaucoma drainage implants. Trans Ophthalmol Soc NZ 1979; 31: 17-26.

14 Molteno ACB, Ancker E, Bartholomew RS. Drainage operations for neovascular glaucoma. Trans Ophthalmol Soc NZ 1980 32: 101-5.

15 Ancker E, Molteno ACB. Molteno drainage implant for neovascular glaucoma. Trans Ophthalmol Soc UK 1982; 102: 122-4.

16 Brown RD, Cairns JE. Experience with the Molteno long tube implant. Trans Ophthalmol Soc UK 1983; 103: 297-312.

17 Molteno ACB. The use of draining implants in resistant cases of glaucoma. Late results of 110 operations. Trans Ophthalmol Soc NZ 1983; 35: 94-7.

18 Molteno ACB, Ancker E, Van Biljon G. Surgical techniques for advanced juvenile glaucoma. Arch Ophthalmol 1984; 102: 51-7.

19 Molteno ACB, Polkinghorne PJ, Bowbyes JA. The Vicryl tie technique for inserting a draining implant in the treatment of secondary glaucoma. Aust NZ J Ophthalmol 1986; 14: 343-54.

20 Teng CC, Chi HH, Katzin HM. Histology and mechanism of filtration operations. Am J Ophthalmol 1959; 47: 16-34.

21 Folberg R, Hargett NA, Weaver JE, et al. Filtering valve implant for neovascular glaucoma in proliferative diabetic retinopathy. Ophthalmology 1982; 89: 286-9.

22 Addicks EM, Quigly HA, Green R, Robin A. Histologic characteristics of filtering blebs in glaucomatous eyes. Arch Ophthalmol 1983; 101: 795-8.

23 Van Buskirk EM. Cysts of Tenon's capsule following filtration surgery. Am J Ophthalmol 1982; 94; 522-7.

24 Regan EF. Scleral cautery with iridectomy, an experimental study. Trans Am Ophthalmol Soc 1963; 61: 219-21.

25 Hitchings RA, Grierson I. Clinicopathological correlations in eyes with failed fistulizing surgery. Trans Ophthalmol Soc UK 1983; 103: 84-8.
26 Herschler J, Claflin AJ, Fiorentino G. The effect of aqueous humor on the growth of subconjunctival fibroblasts in tissue culture and its implications for glaucoma surgery. Am J Ophthalmol 1980; 89: 245-9.

27 Radius RL, Herschler J, Claflin A, Fiorentino G. Aqueous humor change after experimental filtering surgery. Am J Ophthalmol 1980; 89: 250-4.

28 Molteno ACB, Straughan JL, Ancker E. Control of bleb fibrosis after glaucoma surgery by anti-inflammatory agents. $S$ Afr Med J 1976; 50: 881-5.

29 Stanworth A. Conjunctival fibrosis after filtration operations. Trans Ophthalmol Soc UK 1958; 78: 43-58.

30 Epstein E. Fibrosing response to aqueous: its relation to glaucoma. Br J Ophthalmol 1959; 43: 641-7.

31 Molteno ACB. Mechanisms of intraocular inflammation. Trans Ophthalmol Soc NZ 1980; 32: 69-72.

32 Starita RJ, Fellman RL, Spaeth GL, et al. Short and long term effects of postoperative corticosteroids on trabeculectomy. Ophthalmology 1985; 92: 938-46.

33 Migdal C, Hitchings RA. Effect of antiprostaglandins on glaucoma filtration surgery. Trans Ophthalmol Soc UK 1982; 102: $129-32$.

34 Giangiacomo J, Dueker DK, Adelstein E. The effect of preoperative subconjunctival triamcinolone administration on glaucoma filtration. Arch Ophthalmol 1986; 104: 828-41.

35 Mallick KS, Hajeck AS, Parrish R. Fluorouracil and cytarabine inhibition of corneal epithelial cell and conjunctival fibroblast proliferation. Arch Ophthalmol 1985; 103: 1398-402.

36 Gressel MG, Parrish RK, Folberg R. 5-Fluorouracil and glaucoma filtering surgery: I. An animal model. Ophthalmology 1984; 91: 378-83.

37 Heuer DK, Parrish RK, Gressel MG, et al. 5-Fluorouracil and glaucoma filtering surgery: II. Pilot study. Ophthalmology 1984; 91: 384-94.

38 Heuer DK, Gressel MG, Parrish RK, et al. Topical fluorouracil: postoperative administration in an animal model of glaucoma filtering surgery. Arch Ophthalmol 1986; 104: 132-6.

39 Schocket SS, Nirankari VS, Lankhanpal V, et al. Anterior chamber tube shunt to an encircling band in the treatment of neovascular glaucoma and other refractory glaucomas. Ophthalmology 1985; 92: 553-62.

40 Sarkies NJC, Hitchings RA. Silicone tube and gutter in advanced glaucoma. Trans Ophthalmol Soc UK 1985; 104: 133-6.

41 Joseph NH, Sherwood MB, Trantas G, Hitchings RA, Lattimer L. A one piece drainage system for glaucoma surgery. Trans Ophthalmol Soc UK 1986; 105: 657-64.

Accepted for publication 18 August 1987. 